\title{
STRUKTUR TEKS, KONTEKS PERTUNJUKAN, DAN AJARAN ISLAM PADA PALANG PINTU PADA PERNIKAHAN ADAT BETAWI
}

\begin{abstract}
Shelma Aisya
Abstrak. Tujuan penelitian ini yaitu untuk mendeskripsikan struktur teks, konteks pertunjukan, dan ajaran Islam yang terdapat dalam palang pintu pada pernikahan adat Betawi. Metode yang digunakan dalam penelitian ini adalah deskriptif kualitatif dengan metode etnografiPengambilan data dilakukan dengan merekam pertunjukan palang pintu, mewawancarai narasumber, kemudian data yang ada dianalisis sesuai dengan teori. Hasil penelitian ini yaitu dari pantun yang dianalisis, rima dalam pantun pada palang pintu berupa a-a-a-a dan a-b-a-b; diksi yang ada dalam palang pintu berupa diksi denotatif dan diksi kontotatif; dan majas yang digunakan adalah (1) tautologi, (2) antitesis, (3) hiperbola, (4) sinisme, dan (5) metonimia. Konteks pertunjukan pada palang pintu menunjukkan adanya tahapan-tahapan pertunjukan, yakni (1) bagian pembuka, (2) bagian isi, dan (3) bagian penutup; serta unsur-unsur pertunjukan, yakni pemantun, pantun \& dialog, dan penonton. Dalam isi pantun palang pintu, mengandung ajaran Islam, yakni (1) akidah, yakni berhubungan dengan ketauhidan; (2) syariat, berkaitan dengan dasar hukum bagi umat Islam, dan (3) akhlak, dalam pantun yang berisi, antara lain, ajakan membaca serta memahami Quran, ajakan untuk seimbang dalam keduniawian dengan batiniah, ajakan untuk menyayangi anak yatim, mendoakan orang lain, santun terhadap orang tua, komitmen terhadap tanggung jawab yang diberikan orang lain, menghormati suku lain, serta kewajiban suami menjaga istri.
\end{abstract}

Kata kunci: Pantun, Palang Pintu, Betawi, Islam

\section{PENDAHULUAN}

Sebagai bagian dari masyarakat Melayu, masyarakat Betawi mengenal bentukbentuk puisi, yang disebut pantun dan syair. Kesamaan pantun dan syair adalah setiap bait terdiri atas empat baris. Bedanya, pada pantun baris pertama dan kedua disebut sampiran, baris ketiga dan keempat disebut isi pantun. Pola persajakan bunyi akhir baris adalah a-b-ab, sedangkan pada syair keempat barisnya berupa isi dan pola persajakan bunyi akhir adalah a-a-a-a.

Di masa derasnya modernisasi saat ini, keberadaan pantun Betawi dengan fungsifungsi tersebut masih dibutuhkan di masyarakat Betawi. Bentuk penuturan pantun dalam masyarakat Betawi lebih banyak ditemui pada seni pertunjukan masyarakat, seperti pada lenong pada teater tradisional dan palang pintu pada upacara perkawinan adat Betawi.

Palang pintu dilakukan ketika mempelai pria dengan rombongannya datang ke rumah mempelai wanita untuk duduk melaksanakan akad nikah. Namun, kini pertunjukan palang pintu telah mengalami modifikasi, yakni dengan penggunaannya yang tak hanya dalam acara pernikahan adat Betawi. Palang pintu kini turut menjadi bagian berbagai acara. Umumnya, yang diselenggarakan oleh komunitas atau badan pemerintah yang masih memiliki hubungan dengan kota Jakarta dan sekitarnya, seperti acara sunatan, pembukaan acara kepemerintahan, peresmian gedung, serta penyambutan pejabat pemerintahan.

Kebudayaan Betawi kerap bersinggungan dan bergandengan dengan ajaran Islam.Pengaruh agama Islam pada masyarakat Betawi turut terlihat pada pertunjukan palang pintu.Chaer (2015: 18-19) mengatakan bahwa orang Betawi dapat menikah dengan suku mana saja dan ras mana saja asalkan sama-sama beragama Islam. Tanpa Islam, tidak 
akan ada pernikahan. Hal itu tampak dari di dalam palang pintu calon pengantin laki-laki diuji kesiapannya dalam memiliki istri, yakni dengan pembuktian bahwa calon pengantin laki-laki menguasai ilmu silat (yang diwakilkan oleh juru silat), serta memahami ajaranajaran Islam yang tersirat lewat pantun dan lagu sike yang dilantunkan juru pantun. Hal tersebut menjadi kontradiktif jika ditabrakan pada anggapan umum bahwa Jakarta merupakan melting pot. Menurut Bisin dan Verdier (2000: 955) , melting pot adalah asimilasi di satu tempat, peleburan kebudayaan yang dilatarbelakangi oleh pertemuan bahkan pernikahan dari dua orang berbeda etnis dan/atau agama.

Dengan latar belakang tersebut, peneliti berusaha mengungkap ajaran Islam pada palang pintu pada pernikahan adat Betawi. Palang pintu pun diposisikan sebagai bentuk pertunjukan yang melibatkan penonton pada saat itu juga.

\section{METODE PENELITIAN}

Penelitian ini bertujuan untuk Tujuan penelitian ini yakni untuk mengungkapkan struktur teks, konteks pertunjukan, dan makna ajaran Islam dalam palang pintu yang dilaksanakan sebagai bagian dari perkawinan adat Betawi.

Lingkup penelitian ini yaitu pertunjukan palang pintu yang terdapat pada empat pernikahan adat Betawi. Pernikahan tersebut terdiri dari dari pernikahan antara (1) Setiawan bin Suyanto \& Siti Nurhasanah binti Harun Abdul Rahman, (2) Ika Dwi Rahmawati binti Sulaeman \& Muhammad Ridwan bin Kusnalik, (3) Risrian Kharisma binti Ruswandi \& Reza Cahayadi bin Almarahum Parman Supandi, dan (4) pernikahan Randi bin Muhammad Hendrik \& Kusna Yanta binti Afrizal. Palang pintu pada keempat pernikahan tersebut dipertunjukkan oleh kelompok kesenian Betawi Batavia Grup.

Tempat dan waktu pengumpulan data penelitian ini merupakan tempat berlangsungnya keempat pernikahan tersebut, yakni (1) pernikahan yang bertempat di Jalan Ciliwung Ujung RT 009/16 Cililitan, Kramat Jati, Jakarta Timur, pada Sabtu, 11 Oktober 2014, pukul 09.00 WIB; (2) pernikahan yang bertempat di Jalan Menteng Wadas Timur 17 Kelurahaan Pasar Manggis, Kecamatan Setiabudi, Jakarta Selatan, pada Sabtu, 11 Oktober 2014, pukul 10.30 WIB; (3) pernikahan yang bertempat di Gedung Pertemuan Griya Pia Ardhya Garini, Komplek Halim Perdana Kusuma, pada Sabtu, 11 Oktober 2014, pukul 19.00 WIB; (4) dan yang bertempat di Jalan Mampang Prapatan VIII RT 05/01, Kelurahaan Tegal Parang, Kecamatan Mampang, Jakarta Selatan, pada Minggu, 12 Oktober 2014, pukul 09.00 WIB. Data tersebut dianalisis hingga rampung pada Januari 2016.

Teknik pengumpulan data pada penelitian ini yakni dengan merekam empat pertunjukan palang pintu pada pernkahan adat Betawi. Data tersebut peneliti rekam dalam bentuk video, kemudian ditranskripsikan dan diverifikasi keutuhannya dengan menonton kembali video palang pintu. Data yang telah sempurna ditranskrip akan dianalisis dengan struktur teks, konteks pertunjukan, dan ajaran Islam.

Teknik analisis data pada penelitian ini adalah dengan wawancara terhadap narasumber dan menggunakan tabel analisis. Berdasarkan palang pintu pada keempat pernikahan tersebut akan dipilih satu pertunjukan untuk dianalisis struktur teks pantun palang pintu, yakni rima, diksi, dan gaya bahasanya. Lalu satu pertunjukan lain akan dipilih untuk dianalisis unsur-unsur pertunjukannya. Setelah itu data pantun palang pintu tersebut dianalisis dengan ajaran Islam yang dipaparkan oleh Abu Su'ud untuk mengetahui ajaran-ajaran Islam yang terdapat dalam buka palang pintu pada acara pernikahan Betawi. Wawancara narasumber menjadi dilakukan untuk memverifikasi dan mengetahui lebih dalam berkaitan isi pantun serta isi pertunjukan palang pintu. 


\section{HASIL DAN PEMBAHASAN}

Penelitian ini menggunakan teori struktur teks, konteks pertunjukan, dan ajaran Islam untuk menganalisis teks pantun maupun bentuk pertunjukan pada palang pintu. Teks pantun pada pertunjukan palang pintu menujukkan perbedaannya dengan teks sastra tulis. Hal ini terlihat dari bentuk pantun yang terikat dengan aturan adanya rima a-b-a-b atau a-aa-a dan harus terdiri dari 4 baris dengan larik kedua pertama berupa sampian dan larik kedua terakhir berupa sampiran. Perbedaan teks pantun sebagai sastra lisan dari sastra tulis juga didukung oleh adanya konteks pertunjukan, yakni memiliki tahap-tahap pertunjukan. Bagi pemain, tahap-tahap tersebut menjadi acuan mereka dalam mempertunjukkan palang pintu.

Bagi penonton, tahap-tahap pertunjukan juga menunjukkan kekhasan masyarakat Betawi, yakni masyarakat yang egaliter, menjunjung tinggi kekerabatan, dan sifatnya yang terbuka. Selanjuntya, unsur-unsur pertunjukan menunjukkan arti keberadaan penonton di saat pantun disampaikan lewat pertunjukan palang pintu sangat penting. Keterikatan ruang dan waktu antara pemain, teks, dan penonton pada palang pintu menambah perbedaan antara teks sastra lisan dengan teks sastra tulis. Teks sastra tulis memiliki bentuk yang ajeg. Sedangkan teks sastra lisan pada setiap pertunjukan melahirkan satu teks yang berbeda dengan teks pada pertunjukan lainnya karena penyampaiannya didasari dengan kelisanan. Kelisanan erat dengan proses mengingat pada bagian-bagian yang dianggap penting. Jadi, meski tampak terjadi pengulangan teks, namun pengulangan itu tak benar-benar sama, melainkan memiliki variasi yang disesuaikan dengan situasi.

Dari teks yang berulang, seringkali berupa pantun jenaka yang berhasil membuat penonton tertawa. Respons dari penonton itu tampaknya menimbulkan kepuasan bagi para pemain palang pintu. Hal tersebut semakin menguatkan tipikal orang Betawi yang memiliki rasa humor yang tinggi.

Selain pantun jenaka, pantun berulang berupa pantun yang isinya mengedepankan pentingnya Islam dalam kehidupan masyarakat Betawi. Makna Islam bagi masyarakat Betawi tak hanya sampai dalam bentuk ibadah fisik, namun juga tersirat bentuk pengejawantahan ajaran Islam menuju taraf batin.

\section{KESIMPULAN}

Dari penelitian yang dilakukan, didapat hasil berupa bentuk strukutr teks pantun palang pintu, konteks pertunjukan palang pintu, dan ajaran Islam yang terdapat dalam pantun palang pintu. Analisis struktur teks menghasilkan deskripsi penggunaan rima, diksi, dan gaya bahasa pada teks palang pintu.

Analisis konteks pertunjukan menghasilkan deskripsi tahapan pertunjukan palang pintu dan unsur-unsur pada pertunjukan palang pintu. Dari pertunjukan palang pintu ke-4, tahapan pertunjukan palang pintu terbagi menjadi 3 bagian, yakni bagian pembuka, bagian isi, dan bagian penutup. Unsur-unsur pertunjukan pada palang pintu berperan sesuai fungsinya. Pemantun sebagai penyaji dapat mempertunjukan teks dengan baik di hadapan penonton. Keberadaan penonton menjadikan sastra lisan berbeda dengan sastra tulis. Berpadunya ketiga unsur tersebut dapat ditunjukkan dengan respons penonton terhadap teks yang disajikan para pemain palang pintu.

Setelah melakukan penelitian ini, penulis memiliki beberapa saran bagi penulis sendiri dan penelitian selanjutnya. (1) Indonesia memiliki banyak bentuk tradisi lisan, serta masih banyak pula yang belum dikaji. Penelitian struktur teks, konteks pertunjukan, dan isi dari tradisi lisan bisa diterapkan pada tradisi lisannya, selain palang pintu. (2) Penelitian sastra lisan memang memiliki tantangan sendiri, sebab tak sebatas memahami teksnya namun juga kelisanannya. Namun jika berhasil mengungkap kelisanan dan perannya dalam 
Arkhais, Vol. 07 No. 1 Januari-Juni 2016

masyarakat pemiliknya akan sangat bermanfaat bagi peneliti sendiri dan pembaca karena sastra lisan sarat akan kearifan lokal.

\section{DAFTAR RUJUKAN}

Alisyahbana, Sutan Takdir. 1985. Puisi Lama. Jakarta: P.T. Dian Rakyat.

Alqur'an dan Terjemahannya. 2005. Surabaya: CV Karya Utama.

Attas, Siti Gomo. 2015. Ihwal Proses Penciptaan Teks Gambang Rancag dalam Konteks Pertunjukan Melalui Analisis Fungsi dan Makna di Masyarakat Betawi (Disertasi). Bandung: Universitas Pendidikan Indonesia.

Bisin, Alberto \& Thierry Verdier. 2000. ““Beyond The Melting Pot”: Cultural Transmission, Marriage, and The Evolution of Ethnic and Religious Traits". The Quarterly Journal of Economics. President and Fellows of Harvard College and the Massachusetts Institute of Technology.

Chaer, Abdul. 2002. Kamus Dialek Betawi. Jakarta: Masup Jakarta.

. 2012. Folklor Betawi. Jakarta: Masup Jakarta.

2015. Betawi Tempo Doeloe. Jakarta: Masup Jakarta.

Endraswara, Suwardi. 2003. Metode Penelitian Kebudayaan. Yogyakarta: Gadjah Mada University Press.

Hutomo, Suripan Hadi. 1991. Mutiara yang Terlupakan. Surabaya: Himpunan Sarjana Kesusasteraan Indonesia.

Keraf, Gorys. 1984. Diksi dan Gaya Bahasa. Jakarta: PT Gramedia.

Mulyana, Deddy. 2007. Metode Penelitian Kualitatif. Bandung: PT Remaja Rosdakarya.

Mutadlo, Agus Atiq. 2009. “Akulturasi Islam dan Budaya Lokal dalam Tradisi Upacara Sedekah Laut di Pantai Teluk Penyu Kabupaten Cilacap" (Skripsi). Yogyakarta, Fakultas Adab, Universitas Islam Negeri Sunan Kalijaga.

Saidi, Ridwan. 1997. "Sejarah Betawi," Betawi dalam Perspektif Kontemporer, ed. Yasmine Zaki Shahab. Jakarta: Lembaga Kebudayaan Betawi.

Su'ud, Prof. Dr. Abu. 2003. Islamologi: Sejarah, Ajaran, dan Peranannya dalam Peradaban Umat Manusia. Jakarta: PT Rineka Cipta.

Tarigan, Henry Guntur. 1985. Pengajaran Gaya Bahasa. Bandung: Penerbit Angkasa.

Waluyo, Herman J. 2003. Apresiasi Puisi. Jakarta: PT Gramedia Pustaka Utama.

Waridah, Ernawati. 2003. Kumpulan Majas, Pantun, dan Peribahasa plus Kesusastraan Indonesia. Bandung: Ruang Kata. 